\title{
Penerapan Model Pembelajaran Kooperatife Student Facilitator and Explaining untuk Meningkatkan Pemahaman Konsep Fisika pada Siswa Kelas X SMA Negeri 5 Palu
}

\author{
Mawarsih, Syamsu, dan H. Kamaluddin \\ Mawarsih43@gmail.com \\ Program Studi Pendidikan Fisika FKIP Universitas Tadulako \\ Jl. Soekarno Hatta Km. 9 Kampus Bumi Tadulako Tondo Palu - Sulawesi Tengah
}

Penelitian ini bertujuan untuk mengetahui peningkatan pemahaman konsep fisika antara siswa yang mengikuti model pembelajarankooperatif tipe Student Facilitator and Explaining dengan yang mengikuti pembelajaran langsung di kelas X SMA Negeri 5 Palu. Jenis penelitian yang digunakan yaitu eksperimen kuasi dengan desain "The Equivalent Pretest-Posttest Design. Populasi penelitian ini adalah seluruh siswa kelas X SMA Negeri 5 Palu. Teknik pengambilan sampel adalah purposive sampling. Kelas X MIPA 3 sebagai kelas eksperimen dan kelas $X$ MIPA 2 sebagai kelas kontrol. Instrumen pemahaman konsep berupa tes pilihan ganda. Berdasarkan hasil pengolahan data, untuk kelas eksperimen diperoleh rerata skor tes awal adalah 5,77 dan untuk tes akhir adalah 8,10 . Untuk kelas kontrol diperoleh rerata skor tes awal 5,83 dan untuk tes akhir 6,97. Hasil pengujian hipotesis diperoleh nilai $t_{\text {hitung }}>t_{\text {tabel }}(3,13>1,68)$. Hal ini berarti $\mathrm{H}_{1}$ diterima dan $\mathrm{H}_{0}$ ditolak. Dengan demikian dapat disimpulkan bahwa terdapat peningkatan pemahaman konsep fisika melalui penerapan model pembelajaran kooperatif tipe Student Facilitator and Explaining pada siswa kelas X SMA Negeri 5 Palu.

Kata Kunci : Model pembelajaran Kooperatif, Student Facilitator and Explaining, Pemahaman Konsep

\section{PENDAHULUAN}

Pelajaran fisika merupakan salah satu pelajaran yang sulit dipahami oleh siswa. Hal ini terlihat dari hasil belajar fisika siswa disekolah tergolong sangat rendah. Pelajaran fisika sangat diharapkan suatu proses belajar mengajar yang tidak membuat siswa hanya bergantung pada guru, tetapi peran dan pemahaman konsep siswa juga sangat diharapkan dalam proses belajar. Akan tetapi pada kenyataannya proses pembelajaran yang banyak dijumpai bahwa masih banyak siswa yang dalam proses belajar hanya mendengar, mencatat konsep yang telah disampaikan oleh guru dan proses pembelajaran yang berpusat pada guru sehingga menyebabkan siswa pasif. Hasil yang dicapai melalui proses ini menjadikan siswa kurang kreatif dan kurang bisa mengembangkan diri serta sukar untuk mengaplikasikan apa yang telah diperolehnya dalam kehidupan sehari-hari.

Belajar adalah penguasaan pengetahuan atau keterampilan yang diperoleh dari instruksi. Suatu konsep yang dikuasai siswa semakin baik apabila disertai dengan pengaplikasian. Siswa dikatakan telah memahami konsep apabila dia telah mampu mengabstraksikan sifat yang sama, yang merupakan ciri khas dari konsep yang dipelajari, dan telah mampu membuat generalisasi terhadap konsep tersebut [1].

Seorang guru dalam menyampaikan materi perlu memilih metode mana yang sesuai dengan keadaan kelas atau siswa sehingga siswa merasa tertarik untuk mengikuti pelajaran yang diajarkan. Namun sampai saat ini masih banyak guru yang menggunakan metode konvensional. Proses pembelajaran masih berpusat pada guru, sehingga di sini siswa hanya berfungsi sebagai obyek atau penerima perlakuan saja. Oleh karena itu perlu digunakan sebuah metode yang dapat menempatkan siswa sebagai subyek (pelaku) pembelajaran dan guru hanya bertindak sebagai fasilitator dalam proses pembelajaran tersebut. Solusinya adalah dengan menerapkan model pembelajaran student facilitator and explaining.

Model pembelajaran SFE (student facilitator and expalining) menekankan pada pembelajaran yang mengaktifkan siswa dan penyajian materi yang dilakukan dengan menghubungkan kegiatan sehari-hari dan lingkungan siswa sehingga siswa lebih termotivasi untuk belajar. Dalam pembelajaran SFE (student facilitator and explaining) ini 
memanfaatkan pengetahuan dasar yang dimiliki siswa dan fenomena yang sering dijumpai dalam kehidupan sehari-hari dan mengaitkannya dengan konsep yang akan dibahas [2].

Seorang guru dalam menyampaikan materi perlu memilih metode mana yang sesuai dengan keadaan kelas atau siswa sehingga siswa merasa tertarik untuk mengikuti pelajaran yang diajarkan. Namun sampai saat ini masih banyak guru yang menggunakan metode konvensional. Proses pembelajaran masih berpusat pada guru, sehingga di sini siswa hanya berfungsi sebagai obyek atau penerima perlakuan saja. Oleh karena itu perlu digunakan sebuah metode yang dapat menempatkan siswa sebagai subyek (pelaku) pembelajaran dan guru hanya bertindak sebagai fasilitator dalam proses pembelajaran tersebut. Solusinya adalah dengan menerapkan model pembelajaran student facilitator and explaining [3].

Permasalahan tersebut mendasari penelitian ini dalam menerapkan model pembelajaran student facilitator and explaining untuk meningkatkan pemahaman konsep.Model pembelajaran ini diharapkan dapat menjadi solusi untuk mengatasi masalah rendahnya pemahaman konsep siswa. Model pembelajaran yang digunakan oleh guru sangat bermanfaat terhadap hasil belajar mengajar. Untuk menciptakan proses belajar mengajar yang bisa menimbulkan komunikasi dua arah, serta dapat mencapai tujuan pembelajaran fisika yang sesuai dengan waktu yang tersedia maka diarahkan dalam bentuk pembelajaran fisika yang tidak hanya berpusat pada guru tetapi berpusat pada siswa.

Adapun tahap-tahap model pembelajran student facilitator and explaining yaitu:

1. Guru menyampaikan kompetensi yang ingin dicapai

2. Guru mendemonstrasikan/ menyajikan materi

3. Guru membagi dalam beberapa kelompok dan memberi kesempatan siswa untuk menjelaskan kepada siswa lainnya misalnya melalui bagan/peta konsep.

4. Guru menyimpulkan ide/pendapat dari siswa

5. Guru menerangkan semua materi yang disajikan saat itu

6. Penutup.

\section{HASIL DAN PEMBAHASAN}

Pretest (tes awal) digunakan untuk mengetahui kemampuan awal siswa sebelum mengikuti pembelajaran.Data pretest terdiri dari kelas eksperimen dan kelas kontrol yang masing- masing berjumlah 30 siswa.Skor ratarata kelas eksperimen sebesar 5,77 dengan simpangan bakusebesar 2,85. Sedangkan untuk kelas kontrol, skor rata-ratanya sebesar 5,83 dan simpangan baku sebesar 2,58. Selanjutnya pada posttest, skor rata-rata kelas eksperimen sebesar 8,63 dengan simpangan baku3,15 dan untuk kelas kontrol skor rata-ratanya sebesar 6,97 dengan standar deviasi sebesar 2,81. Adapun data hasil penelitian di atas, disajikan pada Tabel 1 :

Tabel 1 Deskripsi skor tes pemahaman konsep fisika siswa untuk kelas eksperimen dan kelas kontrol

\begin{tabular}{lcccc}
\hline & \multicolumn{2}{c}{ Kelas Eksperimen } & \multicolumn{2}{c}{ Kelas Kontrol } \\
\cline { 2 - 5 } Uraian & Tes awal & Tes akhir & Tes awal & Tes akhir \\
\hline Jumlah Siswa & 30 & 30 & 30 & 30 \\
Skor Minimum & 2 & 2 & 1 & 2 \\
Skor Maksimum & 12 & 13 & 12 & 13 \\
Rerata Skor & 5,77 & 8,63 & 5,83 & 6,97 \\
Simpangan Baku & 2,85 & 3,15 & 2,81 & 2,81
\end{tabular}

Uji normalitas pada penelitian ini menggunakan uji Chi-kuadrat dengan kriteria penerimaan, taraf signifikansi $a=0,05$ dan derajat kebebasan $\mathrm{dk}=\mathrm{k}-3$. Berdasarkan hasil perhitungan pretest nilai $\chi^{2}$ hitung untuk kelas eksperimen adalah sebesar 4,34 dan untuk kelas kontrol sebesar 6,95 dengan $\chi^{2}$ tabel sebesar 7,81. Sedangkan hasil perhitungan posttest nilai $\chi^{2}$ hitung untuk kelas eksperimen adalah sebesar 4,64 dan kelas kontrol sebesar 6,24 dengan $\chi^{2}$ tabel sebesar 7,81 .

Uji homogenitas pada penelitian ini menggunakan $u j i$ statistik $F$ dengan taraf signifikansi $a=0,05$ dan untuk pretest nilai varians kelas eksperimen sebesar 8,13 serta kelas kontrol sebesar 6,64. Berdasarkan hasil perhitungan, diperoleh nilai $F_{\text {hitung }}$ sebesar 1,22 sedangkan nilai $F_{\text {tabel }}$ sebesar 1,85 . Sedangkan, untuk posttest nilai varians kelas eksperimen sebesar 9,91 serta kelas kontrol sebesar 7,91. Berdasarkan hasil perhitungan, diperoleh nilai

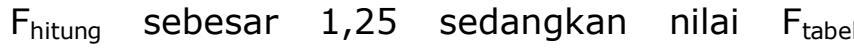
sebesar 1,85 . 
Setelah terpenuhinya uji normalitas dan homogenitas, maka dilakukan uji beda rata-rata (dua pihak) atau $u j i \mathrm{t}$. dimana $\mathrm{H}_{\mathrm{o}}$ diterima jika $-\mathrm{t}_{(1-}$ $\left.{ }_{1 / 2} \alpha\right)<\mathrm{t}<\mathrm{t}_{(1-1 / 2} \alpha_{)}$, diketahui data daripretestyaitu-1,67< $0,09<1,67$. Hal ini berarti, nilai $t_{\text {hitung }}$ berada pada daerah penerimaan $\mathrm{H}_{0}$. Dengan kata lain,bahwa tidak terdapat perbedaan pemahaman konsep fisika siswa antara kelas yang mendapatkan pembelajaran menggunakan modelstudent facilitator and explaining dengan kelas yang mendapatkan pembelajaaran menggunakan model konvensional. Sedangkan untuk data dariposttest yaitut $_{\text {hitung }} \geq t_{\text {tabel }}$ atau 16,02 $\geq$ 1,67. Dengan demikian $H_{0}$ ditolak dan $H_{1}$ diterima, dan dapat disimpulkan bahwa terdapat perbedaan rata-rata pemahaman konsep fisika antara kelompok siswa yang mengikuti model pembelajaran student facilitator and explaining dengan model konvensional.

Diperolehnya hasil tersebut dimungkinkan karena dalam pembelajaran menggunakan model student facilitator and explaining, siswa berperan aktif dalam proses pembelajaran dan secara kreatif saling berinteraksi dengan teman maupun guru, saling bertukar pikiran, sehingga wawasan dan daya pikir mereka berkembang dan menyadari banyak hal atau kejadian yang dapat mereka jumpai dalam kehidupan seharihari yang berkaitan dengan konsep fisika yang mereka pelajari.

Model student facilitator and explaining yang digunakan pada penelitian ini sendiri, mengacu pada beberapa tahapan. Tahap pertama yaitu guru menyampaikan kompetesi yang ingin dicapai.Tahap kedua yaitu guru menyajikan materi. Pada tahap ketiga, siswa sebagai facilitator menjelaskan kepada siswa lain tentang materi yang dipelajari sambil melakukan praktikum. Pada tahap ini, siswa mulai berdiskusi. Pada tahap ini pula, siswa diberi kesempatan untuk melakukan tanya jawab sedangkan guru memberikan penjelasan serta meluruskan jawaban siswa yang dianggap masih kurang tepat. Pada tahap terakhir yaitu, siswa menyimpulkan. Pada tahap ini, siswa dihadapkan pada soal-soal yang berkaitan dengan materi yang sudahdijelaskan.

Berbeda dengan kelas kontrol, model pembelajaran yang diterapkan adalah model pembelajaran konvensional sebagai pembanding kelas eksperimen yang menggunakan model student facilitator and explaining, siswa dalam kegiatan pembelajaran konvensional ini kurang berpikir sendiri dan kurang aktif dalam kegiatan pembelajaran. Hal ini jugadapat mempengaruhi siswa tidak secara aktif dan kreatif dalam proses pembelajaran yang seharusnya siswa lebih banyak berperan. Hal ini sesuai dengan ungkapan [3], bahwa pengaruh kemampuan berpikir kritis pada siswa di kelas eksperimen yang menggunakan model student facilitator and explaining .

Penelitian ini menunjukkan adanya perbedaan antara skor posttest yang diperoleh pada kelas control dan kelas eksperimen yaitu 8,63 untuk kelas eksperimen dan 6,97 untuk kelas kontrol. Sehingga terlihat bahwa hasil posttest kelas eksperimen lebih tinggi dibanding dengan kelas kontrol, dan hasil N-Gain yang diperoleh pada kelas eksperimen sebesar $30,98 \%$ dan kelas kontrol sebesar $11,88 \%$.

\section{KESIMPULAN}

Berdasarkan hasil penelitian dan analisis data baik dari hasil posttest maupun uji statistik disimpulkan bahwa terdapat perbedaan ratarata hasil belajar fisika antara kelompok siswa yang mengikuti model pembelajaran student facilitator and explainingdengan model konvensional pada siswa kelas $X$ IPA SMA Negeri 5 Palu. Kriteria penerimaan $\mathrm{H}_{\circ}$ adalah

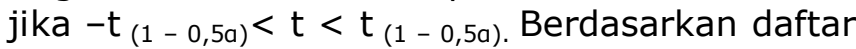
tabel distribusi $\mathrm{t}$ diperoleh harga $\mathrm{t}_{\text {tabel }}=1,85$ sedangkan $t_{\text {hitung }}=16,02$. Hasil uji hipotesis ini memperlihatkan bahwa harga $t_{\text {hitung tidak }}$ berada di dalam daerah penerimaan $\mathrm{H}_{\circ}$ atau dengan kata lain $\mathrm{H}_{1}$ diterima pada taraf nyata a $=0,05$. Adapun kelemahan model ini pada saat melakukan penelitian yaitu membutuhkan waktu yang lama dan susah menentukan siswa yang menjadi facilitator dalam kelompoknya.

\section{DAFTAR PUSTAKA}

[1] Slameto. 2003. Belajar dan Faktor-Faktor Yang Mempengaruhinya. Jakarta: Rineka Cipta.

[2] Purnitawati, Dian. 2011. Penerapan Model Student Facilitator and Explaining Dengan Menggunakan Metode Eksperimen Untuk Meningkatkan Motivasi dan Hasil Belajar IPA Pada Siswa kelas IV di SD No 1 Beratan Tahun Pelajaran 2011/2012. Skripsi (tidak diterbitkan). Singaraja: Undiksha.

[3] Khatimah, Husnul. 2014. Pengaruh Penerapan Pendekatan Realistic Mathematics Education (RME) dengan Pembelajaran Kooperatif Tipe Numbered Heads Together (NHT) Terhadap Pemahaman Konsep Matematika Siswa SMP Negeri 35 Pekanbaru. 
http://repositori.uin-suska.ac.id/2488. di unduh pada tanggal 01 Juli 2015.

[4] Supardin. 2012. Pengaruh Model Pembelajaran Student Fasilitator and Explaining Terhadap Kemampuan Berpikir Kritis Pada Siswa Kelas X Sma Negeri 1 Balaesang. Skripsi tidak dipublikasikan. Palu: FKIP UNTAD 